\title{
Quality of life and sexual activity of women suffering from Polycystic Ovary Syndrome (PCOS)
}

\section{Grażyna Stadnicka' ${ }^{1}$ Anna B. Pilewska-Kozak2 ${ }^{2}$ Celina Łepecka-Klusek², Klaudia Pałucka ${ }^{3}$, Karolina Kostrzewska ${ }^{3}$}

${ }^{1}$ Zakład Podstaw Położnictwa, Wydział Nauk o Zdrowiu, Uniwersytet Medyczny w Lublinie ${ }^{2}$ Katedra i Klinika Ginekologii i Endokrynologii Ginekologicznej, Wydział Nauk o Zdrowiu, Uniwersytet Medyczny w Lublinie ${ }^{3}$ Wydział Nauk o Zdrowiu, Uniwersytet Medyczny w Lublinie

CORRESPONDING AUTHOR/AUTOR DO KORESPONDENCJ: Grażyna Stadnicka

Zakład Podstaw Położnictwa, WNoZ UM w Lublinie ul. Staszica 4/6, 20-081 Lublin

e-mail: grazyna.stadnicka@umlub.pl tel.: 48814486840

Aim. The aim of this study was to search for a correlation between the quality of life and the sexuality of women with polycystic ovary syndrome (PCOS).

Material and methods. The research was made with the use of the WHOQOL)-BREF questionnaire and the FSQ-28 scale. It included 72 women diagnosed with the (PCOS).

Results. A better quality of life in the areas of psychology, social and background relations turned out to be to a moderate degree connected with the reactivity increase on the particular sexual reaction stages, excluding the sexual arousal domain. "Pain" and "relations with a partner" domains had a negative correlation with the given domains of the quality of life. The statistically significant correlation $p<0.05$ was observed between the overall quality of life and the following domains of the sexual response cycle: desire, lubrication, arousal, orgasm, foreplay and the relations with a partner.

Conclusions. 1. All domains of the quality of life of women with PCOS are significantly connected with the majority of domains of the sexual response cycle. 2 . The domains of the sexual response cycle are significantly differentiated by the sense of the quality of life. The perception of health in that respect is irrelevant.

Key words: $\quad$ Polycystic Ovary Syndrome, Quality of Life, Sexuality

STRESZCZENIE JAKOSĆ ZYCCIA I AKTYWNOŚC SEKSUALNA KOBIET ZZESPOLEM POLICYSTYCZNYCH JAJNIKÓW (PCOS)

Cel pracy. Celem pracy było poszukiwanie związku pomiędzy jakością życia, a seksualnością kobiet z zespołem policystycznych jajników.

Materiał i metodyka. Badania przeprowadzono za pomocą kwestionariusza WHOQOL-BREF oraz skali FSQ-28. Objęto nimi 72 kobiety z PCOS.

Wyniki. Lepsza jakość życia w dziedzinach: psychologicznej, relacji społecznych i środowiska była w stopniu umiarkowanym związana ze wzrostem reaktywności na poszczególnych etapach reakcji seksualnej, z wyjątkiem domeny podniecenia. Domeny ból oraz relacje z partnerem korelowały ujemnie z poszczególnymi domenami jakości życia. Stwierdzono istotnie statystyczną zależność p $<0.05$ pomiędzy ogólną jakością życia a następującymi domenami cyklu reakcji seksualnej: pożądaniem, lubrykacją, podnieceniem, orgazmem, oraz z domeną "gra wstępna"i relacje z partnerem.

Wnioski. Wszystkie domeny jakości życia kobiet z PCOS są istotnie związane z większością domen cyklu reakcji seksualnej. Domeny cyklu reakcji seksualnej istotnie różnicuje poczucie ogólnej jakości życia. Percepcja zdrowia jest w tej kwestii bez znaczenia.

Słowa kluczowe: zespół policystycznych jajników, jakość życia, seksualność 


\section{INTRODUCTION}

Infertility is a serious social problem because it affects $10-15 \%$ of couples in the reproductive age $[1,2]$. One of its causes is a polycystic ovary syndrome, the clinical picture of which may be observed in the numerous endocrine-metabolic disorders, amongst which the central position is occupied by the ovary disfunction, as well as symptoms such as: hirsutism $(65 \%)$, obesity $(35-60 \%)$, menstrual disorders (53-66\%) [3, 4, 5, 6, 7].

According to Menning, infertility is a complex of life crises which are psychologically terrifying and emotionally stressful, in which the basic life problem of an individual is determined - that of aim for procreation [8]. Crisis reactions are manifested by the escalated, negatively marked emotions such as: fear, sadness, anxiety, annoyance and anger. The diagnosis and treatment of infertility is often a long-lasting process that does not give a $100 \%$ certainty of recuperation $[2,9,10]$.

The physical and psychological consequences of the PCOS as well as the after - effects of its treatment seem to have a negative influence on the women well - being, their perception of own body image and relations with their environment [11]. The aim of this study was to search for a correlation between the quality of life and the sexuality of women with polycystic ovary syndrome (PCOS).

\section{MATERIALS AND METHODS}

The reaserch obtained the approval from the Ethics Committee of the Medical University of Lublin (KE 0254/334/2014). It was carried out amongst 94 patients of the outpatient infertility treatment clinic. This work incorporates the research results obtained from 72 respondents who have been diagnosed with the PCOS on the basis of clinical symptoms, hormonal and metabolic tests as well as ultrasonography.

The research tool used for the purposes of this work was The World Health Organization Quality of Life (WHOQOL)-BREF questionnaire and the Female Sexual Function Questionnaire (FSQ-28). The WHOQOL questionnaire serves to assess the quality of life and health [12]. The first question (WHO1) evaluates the individual general perception of the quality of life, the second (WHO2) - the individual general perception of one's health, while the remaining ones refer to the following domains of the quality of functioning:

- Domain 1 (DOM1), called somatic is used to assess: activities of daily living (ADLs), dependence on the medical substances and medical help, energy and tiredness, mobility, pain and discomfort, sleep and rest as well as efficiency at work.

- Domain 2 - (DOM2), psychological is used to determine by the examined women, their appearance, feelings, emotions, self-evaluation, world-view, memory and concentration assessment, capacity to study.

- Domain 3 - (DOM3), social, also called communal is used to evaluate interpersonal relations, social support and sexual activity.
- Domain 4 - (DOM4) environment, which assesses: financial situation, freedom, safety and physical protection, health and social care, the house surroundings, capacity to learn new information and skills, participation in recreation and recreational activity, physical environment [10].

The answers of the research participants were assessed on a 5-degree scale, from 1 to 5 . In each domain one could accumulate the maximum of 20 points. The results of the particular domains had a positive direction - the greater number of points, the better quality of life [12].

With the use of the FSQ-28 questionnaire, the sexual activity was assessed at the particular stages of a woman's sexual response cycle. Questions regarding sexual activity referred to the preceding four weeks whereas the remaining questions pertained to the sexual dysfunctions associated with pain, 'foreplay' as well as the physical and emotional relations with partner. In the evaluation of the parameters of the FSQ-28 scale, the points were determined for each stage of the sexual response which would suggest their normal function or the occurrence of disorders. The point values indicating the lack of disorders at the particular stages of a woman's sexual response have been presented in table 1 [13].

Tab. 1. The raw score range of the domains FSQ28 scale and scores suggesting normal sexual functioning [cite 13].

\begin{tabular}{|l|c|c|}
\hline \multicolumn{1}{|c|}{$\begin{array}{c}\text { Stages of the sexual } \\
\text { reaction (FSQ28) }\end{array}$} & $\begin{array}{c}\text { Raw score } \\
\text { range }\end{array}$ & $\begin{array}{c}\text { Scores suggesting normal } \\
\text { function sexual }\end{array}$ \\
\hline Desire & $5-31$ & $\geq 23$ \\
\hline Arousal (sensation) & $4-20$ & $\geq 14$ \\
\hline Lubrication & $2-10$ & $\geq 8$ \\
\hline Cognitive Arousal & $2-10$ & $\geq 12$ \\
\hline Orgasm & $1-15$ & $\geq 12$ \\
\hline Pain & $2-15$ & $\geq 23$ \\
\hline Foreplay (pleasure) & $6-30$ & $\geq 8$ \\
\hline Relationship with partner & $2-10$ & \\
\hline
\end{tabular}

The values of the analysed measurable parameters were presented with the use of the average value and standard deviation while the non-measurable values with the help of the numerical count and percentage. In order to study the relationship between the quality of life and the assessment of sexual deviations, the Spearman's rho correlation was used.

The following level of relevance has been assumed in this work: $\mathrm{p}<0.05$. Calculations were made with the use of the computer program Statistica 10.0 (StatSoft, Poland).

\section{RESULTS}

Research participants were between 20-42 years old (an average age equalled $26.53 \pm 6.85)$. Women aged between 20 -30 constituted the largest group ( $n=51 ; 70.8 \%)$. The age of the first menstruation occurrence within the group equalled approximately $12.86 \pm 1.56$ years. Menstruations occurred on average every $36.40 \pm 7.91$ days. 
The majority of the examined women $(n=49 ; 68.1 \%)$ had never been pregnant before. In case of the other 23 (37.9\%) pregnancy was diagnosed and within that group: for $15(56.0 \%)$ women the pregnancy resulted in the birth of a living infant, in $5(24.0 \%)$ instances necrosis occurred, while in $4(20.0 \%)$ cases spontaneous abortion took place. Menstrual disorders were diagnosed in 53 (73.6) of the respondents, hirsutism in $51(70.8 \%)$, while the lack of menstruation in $9(12.5 \%)$. Abnormal body weight, including obesity (BMI >30) was present in $10(13.9 \%)$ of the research participants, while one in four $(n=19 ; 26.4 \%)$ was overweight (BMI 25-29.9).

The average duration of the PCOS since its diagnosis has equalled $5.78 \pm 4.72$ years. The attempts to treat the syndrome for a period from 1 to 3 years was undertaken by $27(37.5 \%)$ of the research participants. A similar percentage $(n=25 ; 34.7 \%)$ of recipients have been treated for over 6 years, whilst every fourth $(n=20 ; 27.8 \%)$ - from 4 to 6 years.

The data referring to the women's quality of life assessed with the WHOQOL-BREF test has been presented in Table 2. Furthermore, the table displays the results of the general assessment of the quality of life, the self-assessment of one's health condition and of the functioning in the physical, psychological, social domains and in one's environment.

Tab. 2. The quality of life of the women suffering from PCOS within the particular domains of the WHOQOL-BREF scale.

\begin{tabular}{|l|c|c|c|c|}
\hline \multirow{2}{*}{$\begin{array}{c}\text { WHOQOL-BREF } \\
\text { The domains of the quality } \\
\text { of life (WHOQOL-BREF) }\end{array}$} & \multicolumn{2}{|c|}{$\begin{array}{c}\text { Raw score } \\
\text { range }\end{array}$} & \multirow{2}{*}{$\bar{x}$} & \multirow{2}{*}{ SD } \\
\cline { 2 - 4 } & $\mathbf{m i n}$ & $\mathbf{m a x}$ & & \\
\hline General quality of life, WH01 & 1 & 5 & 3.43 & 0.92 \\
\hline $\begin{array}{l}\text { Self-assessment of the health } \\
\text { condition by the sufferers, WH02 }\end{array}$ & 1 & 5 & 2.68 & 1.00 \\
\hline Physical sphere, D0M1 & 5.71 & 19.40 & 15.20 & 2.39 \\
\hline Psychological sphere, D0M 2 & 8.00 & 19.30 & 11.97 & 1.76 \\
\hline Social relations, DOM 3 & 5.33 & 20 & 14.89 & 3.24 \\
\hline Environment, DOM 4 & 9.50 & 19 & 13.28 & 2.07 \\
\hline
\end{tabular}

The general quality of life of the study participants (WHO1 - assessed on a scale from 1 to 5) equalled on average $3.43 \pm 0.92$; the self-assessment of health condition was slightly lower $(2.68 \pm 1.00)$. The assessment of the particular spheres of life (on the scale from 1 to 20) showed that the physical functioning was assessed the most highly (DOM 1 - on average $15.20 \pm 2.39$ ), whereas the psychological functioning was assessed the lowest (DOM 2 - on average $11.97 \pm 1.76$.).

The results of the assessment of the sexual activity and the sexual life of women have been presented in table 3 .

The results of the score estimation suggest that within this group of women disorders occurred at various stages of the sexual response. They were the most escalated in case of desire, orgasm and foreplay, where the average number of points within a group was smaller by over 3 than the lowest score range limit which describes the normal sexual functions.
Tab. 3. The assessment of the sexual life and activity of the women suffering from PCOS.

\begin{tabular}{|l|c|c|c|c|}
\hline \multirow{2}{*}{$\begin{array}{c}\text { Stages of the sexual reaction } \\
\text { (FSQ28) }\end{array}$} & \multicolumn{2}{|c|}{$\begin{array}{c}\text { Raw score } \\
\text { range }\end{array}$} & \multirow{2}{*}{$\bar{x}$} & \multirow{2}{*}{ SD } \\
\cline { 2 - 3 } & $\mathbf{m i n}$ & $\mathbf{m a x}$ & & \\
\hline Desire & 6 & 28 & 18.68 & 6.60 \\
\hline Arousal (sensation) & 8 & 20 & 12.69 & 4.02 \\
\hline Arousal lubrication & 4 & 9 & 6.88 & 2.14 \\
\hline Cognitive Arousal & 4 & 9 & 6.60 & 1.96 \\
\hline Orgasm & 3 & 15 & 9.66 & 3.98 \\
\hline Pain & 3 & 15 & 12.24 & 2.73 \\
\hline Foreplay (pleasure) & 9 & 27 & 19.61 & 6.87 \\
\hline Relationship with partner & 2 & 10 & 6.96 & 2.25 \\
\hline
\end{tabular}

min - minimum value; max - maximum value; $\bar{x}$ - average; SD - standard deviation

The correlation between the quality of life in its chosen domains (somatic, psychological, social and environment) and the sexual response cycle of women is presented in table 4.

Tab. 4. The quality of life within particular domains: somatic, psychological, social and one's environment (WHOQOL-BREF) versus the sexual life and activity of women (FSQ28).

\begin{tabular}{|c|c|c|c|c|c|c|c|c|}
\hline \multirow{3}{*}{$\begin{array}{l}\text { Stages of } \\
\text { the sexual } \\
\text { reaction } \\
\text { (FSQ28) }\end{array}$} & \multicolumn{8}{|c|}{ The domains of the quality of life (WHOQOL-BREF) } \\
\hline & \multicolumn{2}{|c|}{ DoM1 } & \multicolumn{2}{|c|}{ DOM2 } & \multicolumn{2}{|c|}{ DOM3 } & \multicolumn{2}{|c|}{ D0M4 } \\
\hline & $\mathbf{r}_{\mathrm{s}}$ & p & $\mathbf{r}_{\mathrm{s}}$ & p & $\mathbf{r}_{\mathrm{s}}$ & p & $\mathbf{r}_{\mathrm{s}}$ & $\mathbf{p}$ \\
\hline Desire & 0.45 & $<0.000$ & 0.53 & $<0.000$ & 0.66 & $<0.000$ & 0.66 & $<0.000$ \\
\hline $\begin{array}{l}\text { Arousal } \\
\text { (sensation) }\end{array}$ & 0.50 & $<0.000$ & 0.21 & 0.110 & 0.24 & 0.071 & 0.24 & 0.071 \\
\hline $\begin{array}{l}\text { Arousal } \\
\text { lubrication }\end{array}$ & 0.46 & $<0.000$ & 0.50 & $<0.000$ & 0.55 & $<0.000$ & 0.55 & $<0.000$ \\
\hline $\begin{array}{l}\text { Cognitive } \\
\text { Arousal }\end{array}$ & 0.38 & 0.003 & 0.52 & $<0.000$ & 0.41 & 0.002 & 0.42 & 0.001 \\
\hline Orgasm & 0.41 & 0.001 & 0.52 & $<0.000$ & 0.44 & $<0.000$ & 0.44 & $<0,000$ \\
\hline Pain & -0.34 & 0.009 & -0.36 & 0.006 & -0.32 & 0.012 & -0.32 & 0.012 \\
\hline $\begin{array}{l}\text { Foreplay } \\
\text { (pleasure) }\end{array}$ & 0.44 & $<0.000$ & 0.60 & $<0.000$ & 0.49 & $<0.000$ & 0.49 & $<0.000$ \\
\hline $\begin{array}{l}\text { Relationship } \\
\text { with partner }\end{array}$ & -0.47 & $<0.000$ & -0.64 & $<0.000$ & -0.62 & $<0.000$ & -0.62 & $<0.000$ \\
\hline
\end{tabular}

The statistically significant correlation was found between the quality of life in the somatic domain and the majority of women's sexual response cycle domains $(\mathrm{p}<0.05)$. Positive correlations assumed values from 0.38 to 0.50 . A better quality of life in DOM1 was associated, to a low or moderate degree, with the sexuality of women. The negative correlations were observed in the domain of pain and relations with one's partner. A worse quality of life was associated to a minor extent with the more frequent occurrence of pain and to a moderate extent with the worse relations with one's partner. Statistical analysis indicated an important relationship $(\mathrm{p}<0.05)$ between the quality of life in the psychological, social, envirnonment domains and the sexual response cycle with the exception of the arousal domain.

The assessment of the general quality of life and the general perception of women's health is related to their 
Tab. 5. The general quality of life and the general perception of one's health versus the women sexuality.

\begin{tabular}{|l|c|c|c|c|}
\hline \multirow{2}{*}{\begin{tabular}{c}
\multirow{2}{*}{$\begin{array}{c}\text { Stages of the sexual } \\
\text { reaction (FSQ28) }\end{array}$} \\
\cline { 2 - 5 }
\end{tabular}} & \multicolumn{4}{|c|}{$\begin{array}{c}\text { The domains of the quality of life } \\
\text { (WHOQOL-BREF) }\end{array}$} \\
\cline { 2 - 5 } & \multicolumn{2}{|c|}{ WH01 } & \multicolumn{2}{c|}{ WH02 } \\
\hline Desire & $\mathbf{r}_{\mathbf{s}}$ & $\mathbf{p}$ & $\mathbf{r}_{\mathbf{s}}$ & $\mathbf{p}$ \\
\hline Arousal (sensation) & 0.44 & $<0.000$ & 0.19 & 0.123 \\
\hline Arousal lubrication & 0.11 & 0.410 & 0.24 & 0.071 \\
\hline Cognitive Arousal & 0.32 & 0.021 & 0.15 & 0.264 \\
\hline Orgasm & 0.34 & 0.013 & 0.21 & 0.113 \\
\hline Pain & 0.38 & 0.003 & 0.21 & 0.113 \\
\hline Foreplay (pleasure) & -0.16 & 0.230 & -0.23 & 0.091 \\
\hline Relationship with partner & 0.37 & 0.003 & 0.21 & 0.102 \\
\hline
\end{tabular}

WH01 - general quality of life; WH02 - self-assessment of the health condition by the sufferers; $r_{s}=$ Spearman's correlation coefficient; $p$ - values

sexual activity and sexual life. The abovementioned correlations are presented in table 5.

The assessment of the general quality of life was associated with the escalation of sexual disorders in the domains of desire, lubrication, arousal, orgasm, pleasure and relations with partner. The correlation between better quality of life and women sexuality in the abovementioned domains was significantly lower. No important relationship was noted between the general perception of health and the occurrence of the particular stages of the sexual response cycle $(\mathrm{p}>0.05)$. An important correlation on the borderline of relevance was observed between the general perception of health and the evaluation of the relation with one's partner $(\mathrm{p}=0.05)$.

\section{DISCUSSION}

Multi-faceted research carried out amongst the women in Southern Asia by Kumarapeli et al. indicated a significant influence of the occurrence of the PCOS on the general perception of health and on the mental state of the examined women [10]. In personal research, it was observed that the general quality of the life of respondents was good, while the general perception of health was evaluated to be worse. Taking into consideration the particular domains of life, the somatic domain achieved the highest scores, the social environment domains were assessed slightly lower, whereas the psychological domain was evaluated least favourably. These results were compared to the data reported by other authors $[9,14,15]$.
According to Levental's Self-Regulation Model (SRM) the subjective way of perceiving one's illness exerts a strong influence on the way of experiencing its course [16]. Therefore, along with the influence on the somatic domain, the key factor in the treatment of PCOS seems to be the psychological work on the acceptance of body functioning, on emotions, motivation, as well as self-evaluation and self-esteem. It is important because the patients suffering from PCOS and undergoing infertility treatment are under greater risk of developing mental disorders such as depression or anxiety in comparison to healthy women $[14,17]$.

Women suffering from the PCOS are significantly less satisfied with their sexual lives than healthy women $[11,14,18,19]$. In the research by Mansson et al., $43 \%$ of women suffering from PCOS stated that they were less satisfied with their sexuality and felt less attractive to their partners [20]. In the presented material a diversified escalation of the occurrence of sexual response cycle disorders was observed.

The disorders connected with the feeling of desire, pleasure, arousal and orgasm were mentioned the most frequently, while the most rarely - lubrication and emotional arousal. As a result of the undertaken statistical analysis, an important relationship was observed between the general assessment of the quality of life and the escalation of sexual disorders. A better quality of life was associated with the alleviation of sexual disorders, what is also confirmed by the works of other authors $[11,18]$.

The problem of sexuality of women suffering from polycystic ovary syndrome is still poorly understood and equally controversial $[9,19]$. Therefore, further interdisciplinary research is necessary, the results of which might prove to be useful in improving care for this group of people. Since women with PCOS constitute quite a specific group, they require specialistic diagnostics and treatment, and most of all a broadly understood social support.

\section{CONCLUSIONS}

1. All domains of the quality of life of women with PCOS are significantly connected with the majority of domains of the sexual response cycle.

1. The domains of the sexual response cycle are significantly differentiated by the sense of the quality of life. The perception of health is in that respect irrelevant.

\section{Jakość życia i aktywność seksualna kobiet $z$ zespołem policystycznych jajników (PCOS)}

\section{WPROWADZENIE}

Niepłodność dotyczy 10-15\% par w wieku rozrodczym $[1,2]$. Jedną z jej przyczyn jest zespół policystycznych jajników (PCOS), którego obraz kliniczny przejawia się licznymi zaburzeniami endokrynologiczno-metabolicznymi, przy czym centralną pozycję zajmuje dysfunkcja jajnika oraz takie objawy jak: hirsutyzm (65\%), otyłość (35-38\%), zaburzenia miesiączkowania (53-66\%) [3, 4, 5, $6,7]$. Według Menning niepłodność to kompleks kryzysów życiowych, psychologicznie przerażających i emocjonalnie stresujących, w których rozstrzyga się podstawowy problem życiowy jednostki, jakim jest dążenie do prokreacji [8]. Reakcje kryzysowe objawiają się nasilonymi emo- 
cjami, o znaku ujemnym, takimi jak: lęk, smutek, napięcie, rozdrażnienie i złość. Diagnoza i leczenie niepłodności jest często procesem długotrwałym i nie daje $100 \%$ gwarancji wyleczenia $[2,9,10]$. Konsekwencje fizyczne i psychiczne zespołu PCOS oraz następstwa jego leczenia wydają się mieć negatywny wpływ na samopoczucie kobiet, relacje $\mathrm{z}$ otoczeniem oraz postrzeganie przez nie obrazu własnego ciała [11].

\section{CEL PRACY}

Celem pracy było poszukiwanie związku pomiędzy jakością życia, a seksualnością kobiet $\mathrm{z}$ zespołem policystycznych jajników.

\section{MATERIAŁ I METODYKA}

Po uzyskaniu zgody Komisji Bioetycznej Uniwersytetu Medycznego w Lublinie (nr zgody: 0254/334/2014) przeprowadzono badania wśród 94 pacjentek poradni leczenia niepłodności. W niniejszym opracowaniu wykorzystano wyniki badań zebrane od 72 respondentek, u których na podstawie objawów klinicznych, badań hormonalnych i metabolicznych oraz USG zdiagnozowano zespół PCOS.

Wykorzystano kwestionariusz The World Health Organization Quality of Life (WHOQOL)-BREF oraz Female Sexual Function Questionnaire (FSQ-28). Kwestionariusz WHOQOL służy do oceny jakości życia osób zdrowych i chorych [12]. Pytanie pierwsze (WHO1) ocenia indywidualną ogólną percepcję jakości życia, drugie (WHO2) indywidualną, ogólną percepcję własnego zdrowia, natomiast pozostałe dotyczą następujących dziedzin jakości funkcjonowania:

- Domena 1 (DOM1), zwana somatyczną, służy do oceny: czynności dnia codziennego, uzależnienia od substancji leczniczych i pomocy medycznej, energii i zmęczenia, ruchliwości, bólu i dyskomfortu, snu i odpoczynku oraz wydajności w pracy.

- Domena 2 - (DOM2), psychologiczna, służy do określenia przez badane swojego wyglądu zewnętrznego, uczuć, emocji, samooceny, światopoglądu oraz oceny pamięci, koncentracji i możliwości uczenia się.

- Domena 3 - (DOM3), socjalna, zwana też społeczną, wykorzystywana jest do oceny relacji interpersonalnych, wsparcia społecznego i aktywności seksualnej.

- Domena 4 - (DOM4) środowisko, dzięki której ocenia się: zasoby finansowe, wolność, bezpieczeństwo i ochronę fizyczną, zdrowie i opiekę społeczną, otoczenie domu, możliwości zdobywania nowych informacji i umiejętności, udział w rekreacji i działalności rekreacyjnej, środowisko fizyczne.

Odpowiedzi badanych oceniane były na 5-stopniowej skali, czyli od 1 do 5 . W każdej z tych dziedzin można było uzyskać maksymalnie 20 punktów. Wyniki poszczególnych dziedzin miały kierunek pozytywny - im większa liczba punktów, tym wyższa jakość życia [12].

Za pomocą kwestionariusza FSQ-28 oceniano aktywność seksualną na poszczególnych etapach reakcji seksualnej kobiety. Pytania dotyczące aktywności seksualnej odnosiły się do ostatnich 4 tygodni, natomiast pozostałe pytania dotyczyły dysfunkcji seksualnych, związanych z bólem, "grą wstępną" oraz relacji fizycznych i emocjonalnych z partnerem. W ocenie parametrów skali FSQ-28 wyznaczono punkty, za poszczególne etapy reakcji seksualnej, sugerujące prawidłowe ich funkcje lub występowanie zaburzeń. Wartości punktowe, świadczące o braku zaburzeń na poszczególnych etapach reakcji seksualnej kobiety, przedstawiono w tabeli 1 [13].

Tab. 1. Graniczne wartości poszczególnych domen skali FSQ28 oraz wartości punktowe sugerujące prawidłowe funkcje seksualne [cyt. za 13].

\begin{tabular}{|l|c|c|}
\hline $\begin{array}{c}\text { Domeny seksualności } \\
\text { (FSQ28) }\end{array}$ & $\begin{array}{c}\text { Zakres } \\
\text { granicznych } \\
\text { wartości skali }\end{array}$ & $\begin{array}{c}\text { Wartości sugerujące } \\
\text { prawidłowe funkcje } \\
\text { seksualne }\end{array}$ \\
\hline Pożądanie & $5-31$ & $\geq 23$ \\
\hline Uczucie podniecenia & $4-20$ & $\geq 14$ \\
\hline Lubrykacja & $2-10$ & $\geq 8$ \\
\hline Podniecenie emocjonalne & $2-10$ & $\geq 8$ \\
\hline Orgazm & $1-15$ & $\geq 12$ \\
\hline Ból & $2-15$ & $\geq 12$ \\
\hline "Gra wstępna" (przyjemnośc) & $6-30$ & $\geq 23$ \\
\hline Relacje z partnerem & $2-10$ & $\geq 8$ \\
\hline
\end{tabular}

Wartości analizowanych parametrów mierzalnych przedstawiono przy pomocy wartości średniej i odchylenia standardowego, a dla niemierzalnych przy pomocy liczebności i odsetka. Do zbadania związku pomiędzy jakość życia a występowaniem zaburzeń seksualnych zastosowano współczynnik korelacji Spearmana (rs). $\mathrm{W}$ pracy przyjęto poziom istotności $\mathrm{p}<0,05$. Obliczeń dokonano przy użyciu programu komputerowego Statistica 10.0 (StatSoft, Polska).

\section{WYNIKI BADAŃ}

Badane były w wieku 20-42 lata (średnia wieku wynosiła $26,53 \pm 6,85)$. Najliczniejszą grupę $(n=51 ; 70,8 \%)$ stanowiły kobiety pomiędzy 20. a 30. rokiem życia. Wiek wystąpienia pierwszej miesiączki w badanej grupie kobiet wynosił średnio $12,86 \pm 1,56$ lat. Miesiączki występowały średnio co 36,40 \pm 7,91 dni. Większość badanych kobiet $(\mathrm{n}=49 ; 68,1 \%)$ nigdy nie była ciąży. $U$ pozostałych 23 (37,9\%) rozpoznano ciążę, w tym: u 15 (56,0\%) zakończyła się ona urodzeniem żywego dziecka, u 5 (24,0\%) doszło do jej obumarcia, a u 4 (20,0\%) wystąpiło poronienie samoistne. Zaburzenia miesiączkowania zdiagnozowano u $53(73,6 \%)$ respondentek, hirsutyzm u 51 (70,8\%), a brak miesiączki u 9 (12,5\%). Nieprawidłowa masa ciała, w tym otyłość (BMI >30), występowała u 10 $(13,9 \%)$ badanych, a nadwaga (BMI 25-29,9) u co czwartej (19; 26,4\%).

Średni czas trwania choroby (PCOS), od momentu jej zdiagnozowania, wynosił 5,78 \pm 4,72 lat. Próby leczenia zespołu, przez okres od 1 roku do 3 lat, podejmowało 27 $(37,5 \%)$ badanych. Podobny odsetek $(n=25 ; 34,7 \%)$ czynił to ponad 6 lat, a co czwarta badana $(n=20 ; 27,8 \%)$ od 4 do 6 lat. 
Dane na temat jakości życia kobiet, ocenianej przy użyciu testu WHOQOL-BREF, zestawiono w tabeli 2. Zaprezentowano w niej wyniki ogólnej oceny jakości życia, samooceny stanu zdrowia oraz funkcjonowania w dziedzinie somatycznej, psychologicznej, społecznej i w środowisku.

Tab. 2. Jakość życia kobiet z PCOS oceniana kwestionariuszem WHOQ0L-BREF w poszczególnych jej domenach.

\begin{tabular}{|l|c|c|c|c|}
\hline \multicolumn{1}{|c}{$\begin{array}{c}\text { Domeny jakości życia } \\
\text { WHOQ0L-BREF }\end{array}$} & \multicolumn{2}{|c|}{$\begin{array}{c}\text { Zakres granicznych } \\
\text { wartości skali }\end{array}$} & \multirow{2}{*}{$\bar{x}$} & \multirow{2}{*}{ SD } \\
\cline { 2 - 3 } & min. & max & & \\
\hline Ogólna jakość życia, WH01 & 1 & 5 & 3.43 & 0.92 \\
\hline Samoocena stanu zdrowia, WH02 & 1 & 5 & 2.68 & 1.00 \\
\hline Stan fizyczne, D0M1 & 5.71 & 19.40 & 15.20 & 2.39 \\
\hline Stan psychiczny, D0M 2 & 8.00 & 19.30 & 11.97 & 1.76 \\
\hline Relacje społeczne, D0M3 & 5.33 & 20 & 14.89 & 3.24 \\
\hline $\begin{array}{l}\text { Funkcjonowanie w środowisku, } \\
\text { D0M4 }\end{array}$ & 9.50 & 19 & 13.28 & 2.07 \\
\hline
\end{tabular}

min - wartość minimalna; max - wartość maksymalna; $\bar{x}$ - średnia arytmetyczna; SD - odchylenie standardowe

Ogólna jakość życia ankietowanych (WHO1 - oceniana w skali od 1 do 5) wynosiła średnio 3,43 $\pm 0,92$; nieco niżej kształtowała się samoocena stanu zdrowia $(2,68 \pm 1,00)$. Ocena poszczególnych dziedzin życia (w skali 1 do 20), pokazała, że najwyżej oceniano funkcjonowanie fizyczne, natomiast najniżej funkcjonowanie psychologiczne (DOM 2 - średnio 11,97 $\pm 1,76$ ).

Wyniki oceny aktywności seksualnej i życia seksualnego kobiet $\mathrm{z}$ PCOS przedstawiono w tabeli 3.

Tab. 3. Ocena aktywności i życia seksualnego kobiet z zespołem PCOS.

\begin{tabular}{|l|c|c|c|c|}
\hline \multirow{2}{*}{ Domeny seksualności (FSQ28) } & \multicolumn{2}{|c|}{$\begin{array}{c}\text { Zakres granicznych } \\
\text { wartości skali }\end{array}$} & \multirow{2}{*}{$\bar{x}$} & \multirow{2}{*}{ SD } \\
\cline { 2 - 3 } & $\mathbf{m i n}$. & $\mathbf{m a x}$ & & \\
\hline Pożądanie & 6 & 28 & 18.68 & 6.60 \\
\hline Uczucie podniecenia & 8 & 20 & 12.69 & 4.02 \\
\hline Lubrykacja & 4 & 9 & 6.88 & 2.14 \\
\hline Podniecenie emocjonalne & 4 & 9 & 6.60 & 1.96 \\
\hline Orgazm & 3 & 15 & 9.66 & 3.98 \\
\hline Ból & 3 & 15 & 12.24 & 2.73 \\
\hline "Gra wstępna" (przyjemność) & 9 & 27 & 19.61 & 6.87 \\
\hline Relacje z partnerem & 2 & 10 & 6.96 & 2.25 \\
\hline
\end{tabular}

min - wartość minimalna; max - wartość maksymalna; $\bar{x}$ - średnia arytmetyczna; SD - odchylenie standardowe

Wyniki oceny punktowej sugerują, że w tej grupie kobiet występowały zaburzenia na różnych etapach reakcji seksualnej. Najbardziej nasilone były w przypadku pożądania, orgaznu oraz "gry wstępnej”, gdzie uzyskane średnie arytmetyczne w grupie były mniejsze o ponad 3 punkty od najniższej, granicznej liczby punktów, określającej prawidłowe funkcje seksualne.

Zależność między jakością życia w domenach: somatycznej, psychologicznej, socjalnej i środowiska a cyklem reakcji seksualnej kobiet przedstawia tabela 4 .
Tab. 4. Jakość życia w domenach: somatycznej, psychologicznej, socjalnej i w środowiska oceniana kwestionariuszem WHOQOL-BREF, a seksualność kobiet w ocenie skalą FSQ28.

\begin{tabular}{|c|c|c|c|c|c|c|c|c|}
\hline \multirow{3}{*}{$\begin{array}{c}\text { Domeny } \\
\text { seksualności } \\
\text { (FSQ28) }\end{array}$} & \multicolumn{8}{|c|}{ Domeny jakości życia (WHOQOL-BREF) } \\
\hline & \multicolumn{2}{|c|}{ D0M1 } & \multicolumn{2}{|c|}{ DOM2 } & \multicolumn{2}{|c|}{ DOM3 } & \multicolumn{2}{|c|}{ D0M4 } \\
\hline & $r_{s}$ & p & $\mathbf{r}_{\mathrm{s}}$ & $\mathbf{p}$ & $\mathbf{r}_{\mathrm{s}}$ & $\mathbf{p}$ & $\mathbf{r}_{\mathrm{s}}$ & $\mathbf{p}$ \\
\hline Pożądanie & 0.45 & $<0.000$ & 0.53 & $<0.000$ & 0.66 & $<0.000$ & 0.66 & $<0.000$ \\
\hline $\begin{array}{l}\text { Uczucie } \\
\text { podniecenia }\end{array}$ & 0.50 & $<0.000$ & 0.21 & 0.110 & 0.24 & 0.071 & 0.24 & 0.071 \\
\hline Lubrykacja & 0.46 & $<0.000$ & 0.50 & $<0.000$ & 0.55 & $<0.000$ & 0.55 & $<0.000$ \\
\hline $\begin{array}{l}\text { Podniecenie } \\
\text { emocjonalne }\end{array}$ & 0.38 & 0.003 & 0.52 & $<0.000$ & 0.41 & 0.002 & 0.42 & 0.001 \\
\hline Orgazm & 0.41 & 0.001 & 0.52 & $<0.000$ & 0.44 & $<0.000$ & 0.44 & $<0,000$ \\
\hline Ból & -0.34 & 0.009 & -0.36 & 0.006 & -0.32 & 0.012 & -0.32 & 0.012 \\
\hline $\begin{array}{l}\text { "Gra wstępna" } \\
\text { (przyjemność) }\end{array}$ & 0.44 & $<0.000$ & 0.60 & $<0.000$ & 0.49 & $<0.000$ & 0.49 & $<0.000$ \\
\hline $\begin{array}{l}\text { Relacje z } \\
\text { partnerem }\end{array}$ & -0.47 & $<0.000$ & -0.64 & $<0.000$ & -0.62 & $<0.000$ & -0.62 & $<0.000$ \\
\hline
\end{tabular}

Stwierdzono istotny statystycznie związek pomiędzy jakością życia w domenie somatycznej a większością domen cyklu reakcji seksualnej kobiet $(\mathrm{p}<0,05)$. Korelacje dodatnie przyjmowały wartości od 0,38 do 0,50 . Lepsza jakość życia w domenie somatycznej była w niskim lub umiarkowanym stopniu związana z seksualnością kobiet. Korelacje ujemne stwierdzono w domenie ból oraz relacje z partnerem. Gorsza jakość życia była związana w nieznacznym stopniu częstszym występowaniem bólu oraz $\mathrm{w}$ umiarkowanym stopniu z gorszymi relacjami z partnerem. Analiza statystyczna wykazała również istotny związek $(\mathrm{p}<0,05)$ pomiędzy jakością życia $\mathrm{w}$ dziedzinie psychologicznej, relacji społecznych oraz środowiskiem a cyklem relacji seksualnej, $\mathrm{z}$ wyjątkiem domeny podniecenie.

Zależność pomiędzy oceną ogólną jakości życia oraz ogólną percepcją zdrowia a seksualnością badanych kobiet przedstawiono $\mathrm{w}$ tabeli 5 .

Tab. 5. Ogólna jakość życia i ogólna percepcja zdrowia a seksualność kobiet.

\begin{tabular}{|l|c|c|c|c|}
\hline \multirow{2}{*}{$\begin{array}{c}\text { Domeny seksualności } \\
\text { (FSQ28) }\end{array}$} & \multicolumn{4}{|c|}{ Domeny jakości życia (WHOQOL-BREF) } \\
\cline { 2 - 5 } & \multicolumn{2}{|c|}{ WH01 } & \multicolumn{2}{c|}{ WH02 } \\
\cline { 2 - 5 } & $\mathbf{r}_{\mathbf{s}}$ & $\mathbf{p}$ & $\mathbf{r}_{\mathbf{s}}$ & $\mathbf{p}$ \\
\hline Pożądanie & 0.44 & $<0.000$ & 0.19 & 0.123 \\
\hline Uczucie podniecenia & 0.11 & 0.410 & 0.24 & 0.071 \\
\hline Lubrykacja & 0.32 & 0.021 & 0.15 & 0.264 \\
\hline Podniecenie emocjonalne & 0.34 & 0.013 & 0.21 & 0.113 \\
\hline Orgazm & 0.38 & 0.003 & 0.21 & 0.113 \\
\hline Ból & -0.16 & 0.230 & -0.23 & 0.091 \\
\hline "Gra wstępna" (przyjemność) & 0.37 & 0.003 & 0.21 & 0.102 \\
\hline Relacje z partnerem & -0.54 & $<0.000$ & -0.24 & 0.051 \\
\hline
\end{tabular}

WH01 - ogólna jakość życia; WHO2 - samoocena stanu zdrowia; $r_{\mathrm{s}}=$ wartość współczynnik korelacji rang Spearmana; p - poziom istotności statystycznej 
Ocena ogólnej jakości życia korelowała dodatnio $\mathrm{z}$ nasileniem zaburzeń seksualnych $\mathrm{w}$ domenie pożądanie, lubrykacja, podniecenie emocjonalne, orgazm, przyjemność, natomiast korelację ujemną stwierdzono w relacji z partnerem. Dostrzeżono zależność pomiędzy lepszą jakością życia a seksualnością kobiet w wyżej wymienionych domenach. Istotnego związku pomiędzy ogólną percepcją zdrowia a występowaniem zaburzeń, na poszczególnych etapach reakcji seksualnej, nie było $(\mathrm{p}>0,05)$. $\mathrm{Na}$ granicy istotności były relacje $\mathrm{z}$ partnerem $(\mathrm{p}=0,051)$.

\section{DYSKUSJA}

Wieloaspektowe badania, prowadzone wśród kobiet Południowej Azji przez Kumarapeli i współautorów, wykazały istotny wpływ występowania PCOS na ogólną percepcję zdrowia oraz stan psychiczny badanych [10]. W badaniach własnych dostrzeżono, że ogólna jakość życia ankietowanych była dobra. Gorsza była ogólna percepcja zdrowia. Biorąc pod uwagę poszczególne dziedziny życia, kobiety najlepiej oceniały dziedzinę somatyczną, nieco gorzej relacje społeczne i środowisko. Natomiast najbardziej niekorzystna była ocena dziedziny psychologicznej. Wyniki te były porównywalne $\mathrm{z}$ doniesieniami innych autorów $[9,14,15]$.

Zgodnie z Modelem Samoregulacji Leventala (ang. Self-Regulation Model, SRM), subiektywny sposób postrzegania własnej choroby wywiera silny wpływ na sposób doświadczania jej przebiegu [16]. Dlatego, obok oddziaływań na sferę somatyczną, kluczowym czynnikiem w leczeniu PCOS wydaje się być praca psychologiczna nad akceptacją funkcjonowania własnego ciała, emocjami i motywacją, a także nad samooceną i poczuciem własnej wartości. Jest to o tyle ważne, gdyż pacjentki z PCOS, leczone z powodu niepłodności, są narażone na większe ryzyko rozwoju zaburzeń psychicznych, takich jak depresja lub stany lękowe, w porównaniu $\mathrm{z}$ kobietami zdrowymi $[14,17]$.

Samopoczucie kobiet ma duży wpływ na reaktywność seksualną. Zdecydowana większość badaczy twierdzi, że kobiety z PCOS są znacząco mniej zadowolone ze swojego życia seksualnego niż kobiety zdrowe $[11,14,18,19]$. W badaniach Mansson i współautorów 43\% kobiet $\mathrm{z}$ tym zespołem przyznało się, że nie są zadowolone ze swojej seksualności i czują się mniej atrakcyjnie dla partnera [20]. W prezentowanym materiale dostrzeżono zróżnicowane nasilenie występowania zaburzeń w cyklu reakcji seksualnej. Najczęściej stwierdzano zaburzenia w zakresie pożądania, przyjemności, uczucia podniecenia i odczuwania orgazmu. Najrzadziej lubrykacji i podniecenia emocjonalnego. W wyniku przeprowadzonej analizy statystycznej stwierdzono istotny związek między ogólną oceną jakości życia a nasileniem zaburzeń w cyklu reakcji seksualnej. Lepsza jakość życia była związana, ze rzadszym występowaniem zaburzeń seksualnych, co potwierdziły również prace innych autorów $[11,18]$.

Seksualność kobiet z zespołem policystycznych jajników to problem wciąż mało poznany, a zarazem kontrowersyjny $[9,19]$. Potrzebne są zatem dalsze, interdyscyplinarne badania, których wyniki być może okażą się przydatne w doskonaleniu opieki nad tą grupą osób. Kobiety te bowiem stanowią dość specyficzną grupę pacjentek, wymagają specjalistycznej diagnostyki i leczenia, a przede wszystkim szeroko rozumianego wsparcia.

\section{WNIOSKI}

1. Wszystkie domeny jakości życia kobiet z PCOS są istotnie związane z większością domen cyklu reakcji seksualnej.

1. Domeny cyklu reakcji seksualnej istotnie różnicuje poczucie ogólnej jakości życia. Percepcja zdrowia jest w tej kwestii bez znaczenia.

\section{PIŚMIENNICTWO/REFERENCES}

1. Gurunath S, Pandian Z, Anderson RA et al. Defining infertility--a systematic review of prevalence studies. Hum Reprod Update. 2011; 17(5): 575-588.

2. Łepecka-Klusek C, Pilewska-Kozak AB, Jakiel G. Infertility - a disease or not according to the WHO definition. Med Og Nauk Zdr. 2012; 18(2): 163-166.

3. Shannon M, Wang Y. Polycystic Ovary Syndrome: A common but often unrecognized condition. J Midwifery Women's Health. 2012; 57(3): 221-230.

4. Amsterdam ESHRE/ASRM-Sponsored 3rd PCOS Consensus Workshop Group. Consensus on women's health aspects of polycystic ovary syndrome (PCOS). Hum Reprod. 2012; 27(1): 14-24.

5. Amato MM, Galluzzo A, Finocchiaro $S$ et al. The evaluation of metabolic parameters and insulin sensitivity for a more robust diagnosis of the polycystic ovary syndrome. Clin Endocrinol. 2008; 69(1): 52-60.

6. Gambineri A, Pelusi C, Vicennati $V$ et al. Obesity and the polycystic ovary syndrome. Int J Obes Relat Metab Disord. 2002; 26(7): 883-896.

7. Ekback M, Wijma K, Benzein E. "It is always on my mind": women's experiences of their bodies when living with hirsutism. Health Care Women Int. 2009; 30(5): 358-372.

8. Menning BE. The psychosocial impact of infertility. Nurs Clin North Am. 1988; 117(1): $155-163$.

9. Elsenbruch S, Hahn S, Kowalsky D et al. Quality of life, psychosocial well-being, and sexual satisfaction in women with polycystic ovary syndrome. J Clin Endocrinol Metab. 2003; 88(12): 5801-5807.

10. Kumarapeli VL, Seneviratne R, Wijeyaratne A. Health-related quality of life and psychological distress in polycystic ovary syndrome: a hidden facet in South Asian women. BJOG. 2011; 118(3): 319-328.

11. Janssen $0 E$, Hahn $S$, Tan $S$ et al. Mood and sexual function in polycystic ovary syndrome. Semin Reprod Med. 2008; 26(1): 45-52.

12. WHOQOL-BREF. Introduction, administration, scoring and generic version of the assessment. Field Trial Version. WH0, Genewa 1996.

13. The Female Sexual Function Questionnaire (SFQ-28). Background and Scoring. Pifzer Ltd, Sandwich 1997, France.

14. Coffey S, Mason H. The effect of polycystic ovary syndrome on health-related quality of live. Gynecol Endocrinol. 2003; 17(5): 379-386.

15. Dilbaz B, C Inar M, Ozkaya E et al. Health related quality of life among different PCOS phenotypes of infertile women. J Turk Ger Gynecol Assoc. 2012; 13(4): 247-252.

16. Leventhal $H$, Leventhal $E A$, Van Nguyen T. Reactions of families to illness: theoretical models and perspectives. In Turk D end Kerns R, eds. Health, illness, and families: a life-span perspective. New York: John Wiley 2005: 108-145.

17. Dahan MH, Nguyen SL, Abu II. Social implications of policystic ovary syndrome (PCOS). 84 TH Meeting of the Endocrine Society, San Francisco 2002, June 19-22.

18. Drosdzol A, Skrzypulec V, Mazur B et al. Quality of life and marital sexual satisfaction in women with polycystic ovary syndrome. Folia Histochem Cytobiol. 2007; 45 (Suppl. 1): 93-97.

19. Stovall DW, Scriver JL, Clayton AH. Sexual function in women with polycystic ovary syndrome. J Sex Med. 2012; 9(1): 224-230.

20. Mansson $M$, Norstrom K, Holte J et al. Sexuality and psychological wellbeing in women with polycystic ovary syndrome compared with healthy controls. Eur J Obstet Gynecol Reprod Biol. 2011; 155(2): 161-165.

Praca przyjęta do druku/Manuscript received:

31.10.2016

Praca zaakceptowana do druku/Manuscript accepted: 23.05.2016

Tłumaczenie/Translation: Ewa Partyka 